\title{
Multimediality and Intermediality in Zuko Džumhur's Literary Work: Relationship between Drawings and Text
}

\author{
Mirzana Pasic Kodric \\ Faculty of Education, University of Sarajevo, Sarajevo 71 000, Bosnia and Herzegovina
}

Received October 19, 2020; Revised January 7, 2021; Accepted January 20, 2021

\section{Cite This Paper in the following Citation Styles}

(a): [1] Mirzana Pašić Kodrić , "Multimediality and Intermediality in Zuko Džumhur's Literary Work: Relationship between Drawings and Text," Linguistics and Literature Studies, Vol. 9, No. 1, pp. 27 - 35, 2021. DOI: 10.13189/lls.2021.090104.

(b): Mirzana Pašić Kodrić (2021). Multimediality and Intermediality in Zuko Džumhur's Literary Work: Relationship between Drawings and Text. Linguistics and Literature Studies, 9(1), 27 - 35. DOI: 10.13189/lls.2021.090104.

Copyright@2021 by authors, all rights reserved. Authors agree that this article remains permanently open access under the terms of the Creative Commons Attribution License 4.0 International License

\begin{abstract}
Zuko Džumhur's literary work has an impressive multimedial and intermedial character, not only his travelogues, but generally the entire body of his creative work. This paper intends to precisely examine the nature of his work, where the emergence of intermediality, i.e. the relationship between drawings and text, can be considered as an additional thematisation. It would be difficult to conclude whether the highly hybrid and very complex nature of the multimedial and intermedial nature of Zuko Džumhur's work stem from the poetics of Modernism. Especially when it comes to the Avant-garde heritage, which, as well as Modernism, is very close to him, or the influence of remarkable earlier travelogues, which also link the drawing to a text like e.g. Evliya Çelebi etc. However, it is certain that the reasons behind his unique discourse can also be found in the fact that Zuko Džumhur, by his nature, was a very multidimensional person of many preferences, talents, professions and interests. This paper could not exhaust all the aspects of this extremely complex topic, but did try to draw attention to the unique discourse, role and place of Zuko Džumhur's work as one of the most significant Bosniak and Bosnian-Herzegovinian travel writers, and beyond, with a significant place in the wider South Slavic literary context too.
\end{abstract}

Keywords Multimediality, Intermediality, Drawing, Text

\section{Introduction}

Zuko Džumhur was a writer, but also a painter, cartoonist, journalist, art critic, set designer, author of sketches for theatrical costumes, screenwriter, editor of magazines, etc. His entire work has not yet been sufficiently valorized and researched, at least not in the way it deserves (cf. Pašić 2012; Pašić Kodrić 2017, etc.). Namely, Zuko Džumhur had a rare authorial personality, being talented for different media and different art forms. Only such an authorial personality could achieve his full artistic expression by choosing different means of artistic expression and realization. On the other hand, Zuko Džumhur himself said that he was a curious man, and it seems that only by using various means of expression in art, he nurtured his own curiosity, i.e. his extremely talented nature. It seems that this is exactly how he got to know himself and his artistic possibilities, building and reacquainting himself with his own achievements in his very original creative poetics. Džumhur's discourse is, therefore, difficult to compare with other phenomena, i.e. with the work of any of his literary-artistic predecessors and contemporaries. Man travels to see himself, not just countries and people. I am a curious man, are the words of Zuko Džumhur himself in a review of his work, i.e. his literary and artistic work and life (Radioenciklopedija bh. stvaralaštva - Hodoljublja 2015). The causes of multimediality and intermediality in the work of Zuko Džumhur could be sought precisely in his curious journey 
through the possibilities of his own creation in general.

\section{Materials and Methods}

In this paper, the method predominantly used is the method of narrative analysis, which includes the semiotic analysis method, as well as the method of literary history and criticism. Strong postcolonial and gender hubs of his poetics are also mentioned, which play a big role in the multimedial and intermedial context of Zuko Džumhur's discourse. Hasan Tijanović wrote about the nature of multimediality in Zuko Džumhur's travelogues, and precisely described the various media areas of this author's work, dividing them into three basic multimedia hubs: drawing, word, television, i.e. more precisely caricature and drawing as an important element of travel writing and other literary works of the author. Also, artistic, literary, travel and documentary texts and, finally, television travelogues are worth noting (cf. Tijanović 2008: 83). However, what this division omits is the fact that Zuko Džumhur's television travelogue was preceded by his radio travelogue, and that Džumhur read his first travelogues on the radio. In this regard, it should be noted that radio (along with drawing, word and television, as stated by Hasan Tijanović) is one of his initial multimedial hubs. Namely, Zuko Džumhur's radio travelogue was, in fact, a precursor to everything that later became his television travelogue.

First came the radio where I was reading. I think that radio is a modern medium, people should read their texts, poetry or prose on the radio. That's wonderful! Then, when television came, I saw that in addition to words, there are pictures, and music, and colors, which enriches travel literature. However, travelogue on television soon became, in a way, an educational show. (Radioenciklopedija bh. stvaralastva - Hodoljublja 2015)

Also, according to the stylistic criteria, Hasan Tijanović classified and systematized the complex world of Džumhur's drawings into four groups (cf. Tijanović 2008: 88-100):

1. Caricatures, which along with the literary text follow and comment on all the breadth and complexity of life (from thematically local to the universal world, expanding spatially and temporally, all the way to caricatured historical "visions" of kings, sultans and other prominent historical figures, etc.)

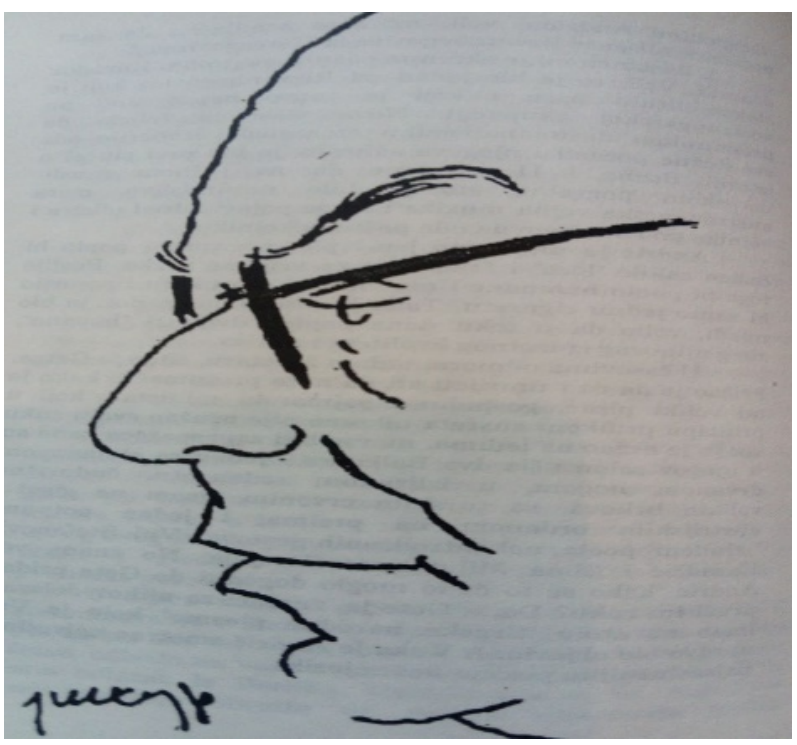

Figure 1. Example of a caricature: Andrič's elusive character (Džumhur 1991a: 90)

2. Croquis (most often portraits, buildings or city interiors)

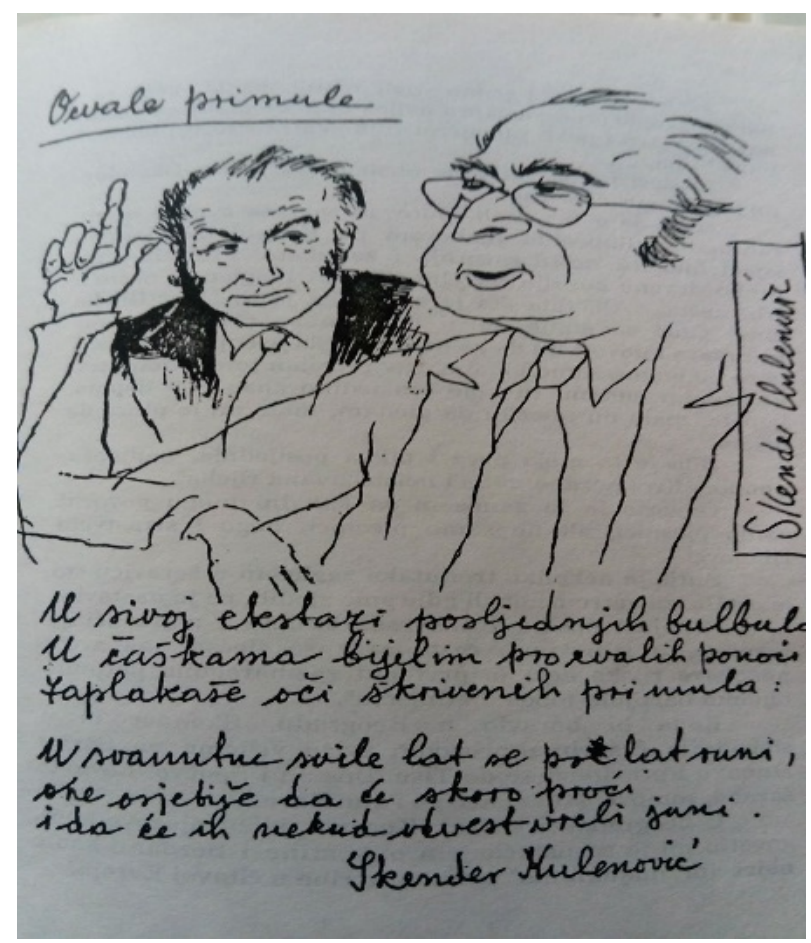

Figure 2. Example of croquis - portrait: Poet on Clear Rivers (Džumhur 1991a: 47) 


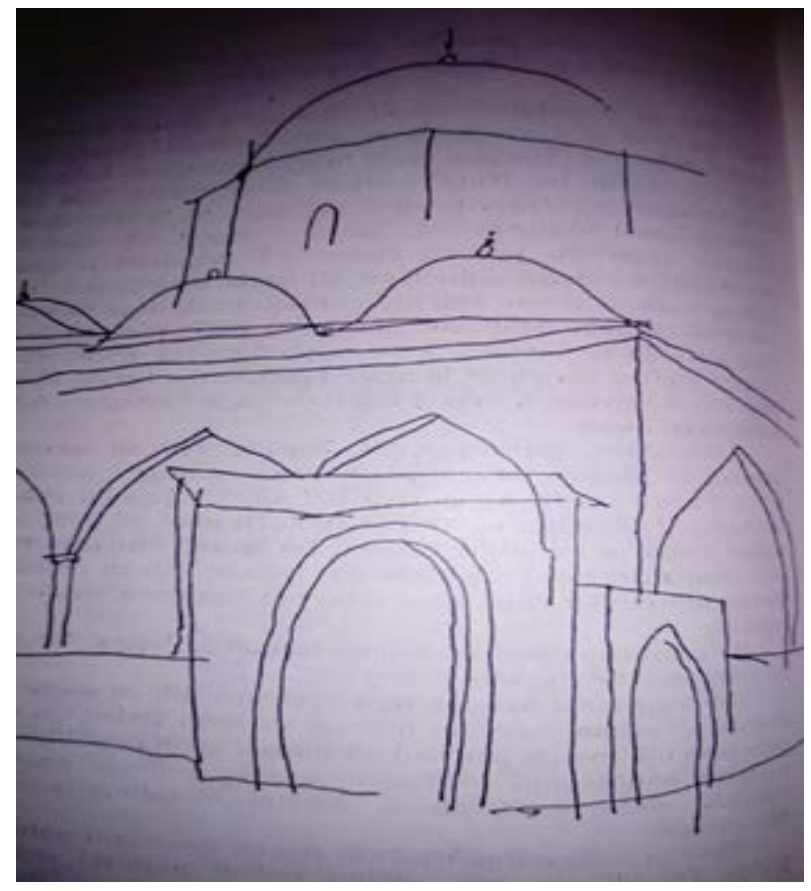

Figure 3. Example of a croquis - building: Mostar (Džumhur 1991b: 164)

3. Drawings inspired by oriental construction and ornamentation (with a series of ornate details as on embroidery, arabesques or carvings)

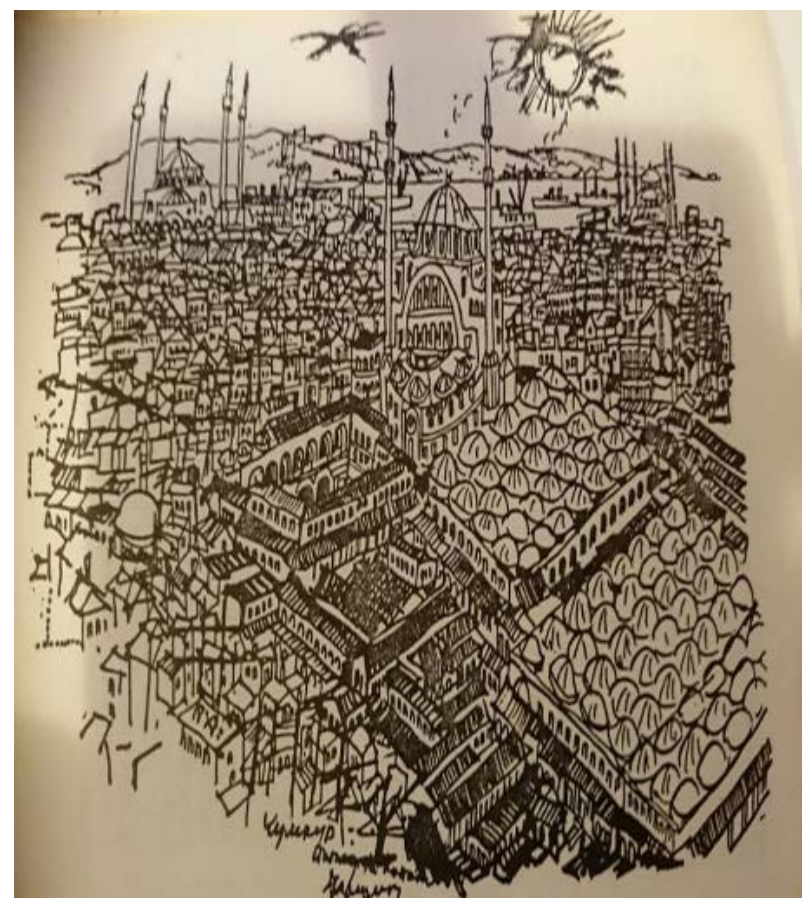

Figure 4. Example of a drawing which is inspired by oriental architecture and ornaments (Džumhur 1991c: 39)

4. Drawings that are the result of the synthesis of the previous three types of art contributions (with a strong combination of visual and textual content and a strong note of intermediality)

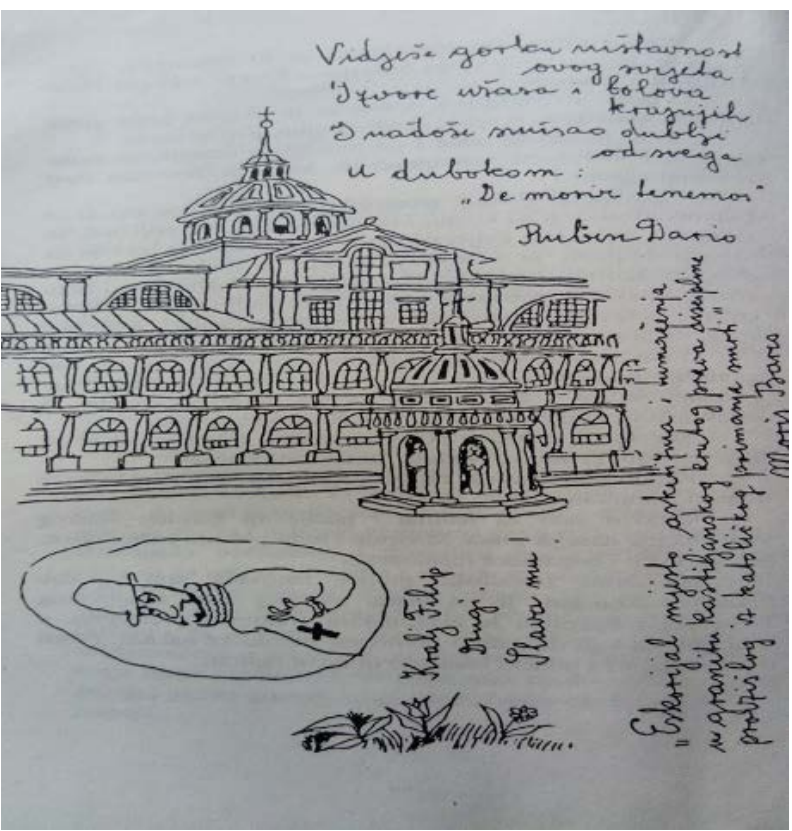

Figure 5. Example of a drawing with a combination of visual and textual content In the Chambers of El Escorial (Džumhur 1991 d: 98)

Intermediality, by its definition, implies a phenomenon in which knowledge of a work from one art is relevant for understanding a work in another art, and above all an interconnection, i.e. "mixing" of creative-expressive means of different arts. The relationship of works of art to non-artistic phenomena can also be categorized in this sense - documents in the novel, playing plays in real spaces other than the stage (cf. Marković et al. 1988: 7). Zuko Džumhur's work is particularly complex in this sense. Namely, Zuko Džumhur, graduated from the Second men's real gymnasium in Sarajevo, where his first watercolors were placed in the gymnasium's corridor and where he read a great deal in the Great library "Prosvjeta". He studied at the Faculty of Law in Belgrade, but at the same time he also studied at the Academy of Fine Arts in the class of professors Petar Dobrović and Milo Milutinović and published his first drawings in Narodna armija during the Second World War. All this clearly shows that for an author like Zuko Džumhur, multimediality and intermediality were, from the very beginning, in fact, the most natural forms of his artistic expression. Namely, this Bosnian author from his very beginnings encompassed a love for both: painting and reading. Later, in the work of this author, this will be exemplified as an unbreakable connection between the image and the text. There were no picture books in my childhood. My first big reading was Uncle Jova Zmaj. I started reading more intensively in Sarajevo. Mr. Vasilije worked in the Great library of Prosvjeta and he directed me to read Andrić, Crnjanski, Matoš, Kranjčević, Humo, Muratbegović, Krklec, Krleža. Still, drawing is my first talent. In the second grade of the Sarajevo gymnasium, professors Pero Popović and Vojo Hadžidamjanović 
placed my first watercolors in the corridor of the gymnasium [...]. When I watched Laza Drljaća painting Stara Ćuprija in Konjic as a child, I thought I met a wizard. Then $I$ decided $-I$ will be a painter (Radioencyclopedia of $\mathrm{BiH}$ creativity - Hodoljublja 2015).

This is confirmed by Džumhur's later engagements as an illustrator and cartoonist in various magazines: Jež, Borba, Oslobođenje, Vjetrenjača, Politika, Danas and Nin. He was a permanent cartoonist of Politika during the lifetime of the famous cartoonist Pjer Križanić, and he published over 10.000 caricatures. On the other hand, in addition to his love for painting and literature, Džumhur expressed a great interest in history. His extensive knowledge in this field reflected on the character of his literary poetics in general. But also on the nature of his artistic expression - his illustrations and caricatures. This was mostly due to the fact that Džumhur was just happy to paint the past from his own perspective. Džumhur's love for world history and his deep knowledge of this field will leave a great imprint on the nature of his poetics.

Guided by the idea that travel policy and the spatial dimensions of knowledge are crucial for understanding postcolonial and gender criticism, it must be mentioned that postcolonial and gender reading of Zulfikar Z. Džumhur's travel narrative work offers rich material for such analyses and interpretations. This task is even more interesting, but also more demanding, because Bosnian travel literature seems to be an almost unknown field both in the context of postcolonial research and in the context of gender criticism research (cf. Pašić Kodrić, 2020a: 1083). Džumhur's travel narrators, as well as the drawings in his travelogues, sympathize with the victims and consequences of the legacy of androcentric imperial visions. It is a compassion for a brutal past in which many women, precisely because of imperial ideologies of land tenure, have been victims for centuries of "living land tenure," trapped in a vicious hopeless cycle of suffering, prostitution, and exploitation. In general, Dzumhur's travel poetics abounds with demystifications of history.

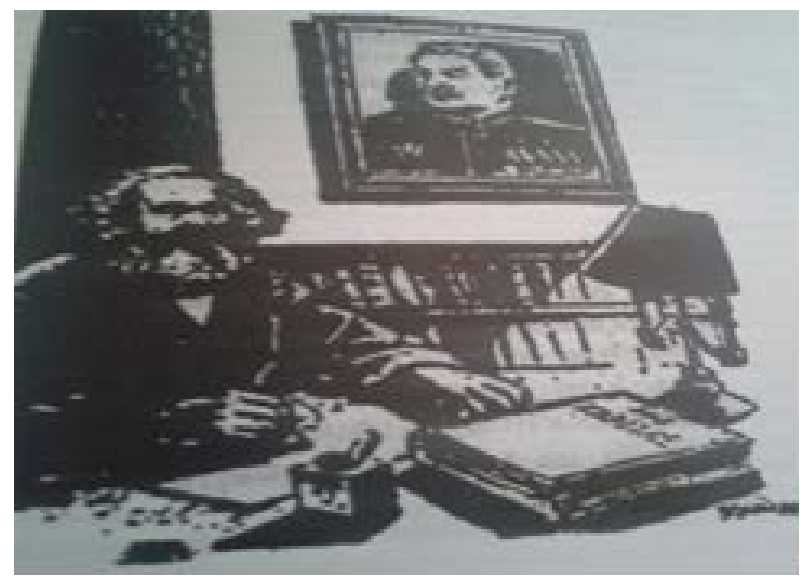

Figure 6. Džumhur's famous caricature of Karl Max and Stalin from 1949 (Tijanović 2008: 85)
His famous caricature of Karl Marx and Stalin, published in the magazine Jež in 1949, made a witty historical anachronism, because Marx and Stalin are "switched in time".

The fact that Marx and Stalin were historically "switched" in Džumhur's famous caricature is one of the typical examples of the author's characteristic demystification of the past, which is, obviously, the method that Džumhur nurtured both in literature and in drawing, whereby this type of interest can be sought precisely in the author's first talent - painting. Dzumhur's contemporaries and collaborators also drew attention to the fact that history had a huge impact on his work in general. As he spoke, it seemed as if the past was constantly crouching on his shoulder, like colourful parrots sitting on the shoulders of retired captains of a long voyage (Kapor 1993: 9. If we add to all of this that caricature, by its definition, implies a simple drawing or a short description which emphasizes the most important features in an exaggerated and humorous or satirical way (cf. Palić, Šehović 2010: 491), a very concrete conclusion is reached: Džumhur's macro-poetics and writing, and painting often demystify history. And so, it always offers a new and different interpretation of history. This is because a caricature is a drawing that in short strokes, usually with irony, emphasizes the most noticeable external and character traits of a character, phenomenon, event, etc. Also, as a word in its figurative meaning, caricature represents what is a complete failure, something that distorts, ridicules, something that makes a senseless image, occurrence or event (cf. Rječnik stranih riječi bosanskoga jezika 2011: 593). Considering that at the root of the word (Italian caricare) it means exaggeration, but also pretense. Caricature, for good reasons, is an artistic expression that can be very nicely intermedially connected with an artistic text which by its nature also implies pretense, ie. fictionality, but also exaggeration in the textual shaping of reality. Hence the most intimate connection between Zuko Džumhur's travel writing poetics in general and his intermediate "variant" in the form of a caricature is very clearly revealed. It is known that Zuko Džumhur drew some of the most significant caricatures in the Balkans, that he was long celebrated with caricatures such as the caricature of Karl Marx and Stalin. The same applies to caricatures or drawings of Ivo Andrić, Skender Kulenović, Gustav Krklec and many others. However, from today's perspective, it seems necessary to examine the ways in which Zuko Džumhur himself spoke about himself in his work and how he painted his own caricatures. And also to examine what is the connection between these self-portraits and the text of his work. In this sense, his book of stories Journey on a White Boat (1991), which abounds in autobiographical elements, seems especially significant, although we can tell the same about numerous author's travelogues in which Džumhur intermedially combined text and images 
by his autodiagetic or autodiegetic narrators (cf. Pašić Kodrić 2015). At the very beginning of the book Journey on a White Boat, Zuko Džumhur, as the author, addresses the reader directly, beginning his journey with a return to childhood, during the first grade of primary school. That journey - a return to childhood, although not a travelogue, still retains the forms of the well-known and dominant Džumhur's travelogue discourse through constant shaping, research and transmission of identity, which is precisely the primary task of travel literature (cf. Lipski 2018: 1). What the reader must immediately notice is that in this preface the author writes a part of the text in his own handwriting, in two letters - Latin and Cyrillic, where the preface itself in handwriting also represents not only the text but also the image, especially from the position of the present time, when the very notion of the image has undergone significant changes.

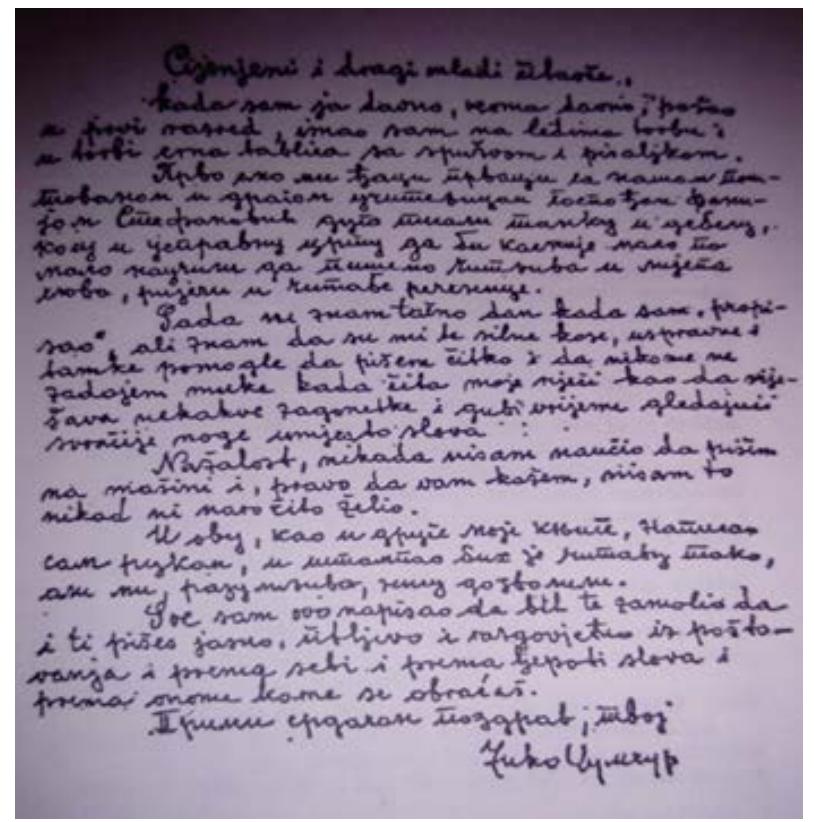

Figure 7. Džumhur's own preface written in his handwriting in his book Journey on a White Boat (Džumhur 1991a).

What is especially interesting is that Džumhur addresses this preface to the "esteemed and dear young reader", which, in fact, reveals a completely new dimension of Zuko Džumhur's intermedial work. All of this has not been written about thus far. Džumhur certainly sees the meaning of his intermediality in the alienation of the text with images, so the combination of text and image is more interesting to young readers. The first story in this book is What a life, in which an auto-homodiegetic narrator (modelled as the author Zuko Džumhur) begins a story about his own childhood in Belgrade on Dorćol, with a detailed description of Belgrade's Kalemegdan Park during his childhood. The homodiegetic narrator will present very precisely what that place represented to children and what Mali Kalemegdan looked like, how most of Kalemegdan was once held by the army, and the zoo was later built in that place etc. Later in the story, the homodiegetic narrator describes the children's joy and general excitement about the opening of the zoo, describing how his fascination with monkeys lasted from that period... And how he had no idea that later in his life he will have a pet Olgica - a female monkey: At that time, I had no idea that one day I would travel to distant Asia and bring a little monkey from Asia, female monkey Olgica and carry her on my shoulder for a walk on the old Belgrade where I played as a child (Džumhur 1991a: 10). However, what is especially interesting in this short story is precisely the connection of its plot with the drawing that accompanies the story. Namely, in the story What a life, the auto-homodiegetic narrator will talk mostly about the memory of his own childhood, about his joy and the joy of other children because of the opening of the Belgrade Zoo, about the teacher Fanija Simonović, who was the first to tell the children the good news, etc. But nowhere in this story will he mention who is, in fact, the most important character of the whole story- the character of the guardian of Kalemegdan Park - Uncle Jelisija. Actually, he is very impressively drawn on the paper next to the story, but his name is not even mentioned in the text. Along with the very dominant caricature of Uncle Jelisija, a special story will be told about him and his stick, i.e. " his little rod", whose "purpose" is also not revealed in the story, but is written with the caricature as an integral part (not as an integral part of the story text). However, he always had one rod, and you already know how it is - hope not needed, but children are children! (Džumhur 1991a: 9)

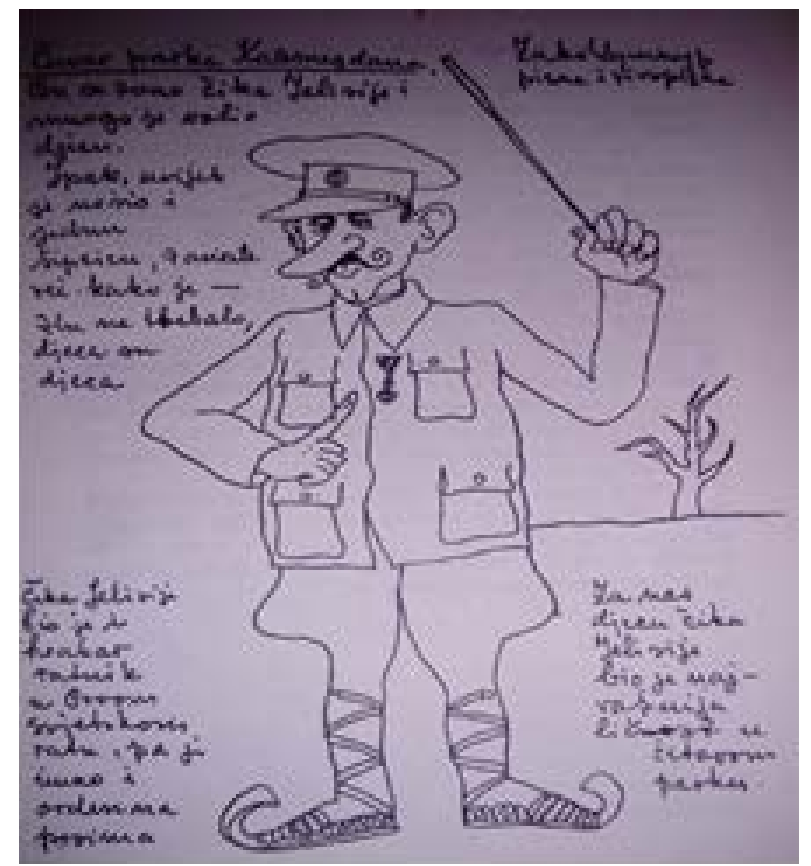

Figure 8. Caricature of Uncle Jelisija as an example of introducing the main character through drawings in the text of the story What a life (Džumhur 1991a: 9). 
The text with the drawing of the park guard of Kalemegdan clearly shows why, after describing himself, other children, the Kalemegdan place, the teacher Fanija Simonović and the female monkey Olgica, the homodiegetic narrator of Džumhur's story "left” the text”, and the storytelling "went into the drawing". Namely, "hitting children" is a difficult topic, terrible for children, but, is unfortunately, the traditional "famous practice" in the upbringing and education of children at that time.

For us children, Uncle Jelisija was the most important person in the entire park (Džumhur 1991a: 9). A similar example of the inseparability of text and drawings in Zuko Džumhur's work is offered by the story Journey by White Boat, which with its text and caricature represents a whole auto-portrait of a homodiegetic narrator (modelled as the author Zuko Džumhur), but where the narrator is also its main actor. Namely, as in the previous story What a life, the narrator in this story again retrospectively tells about the magic of his own childhood and all the children's joys that accompany it like a rubber ball (which was a rarity at the time), tram rides, boat trips to Zemun or Pančevo, Belgrade confectioneries with oriental drinks and sweets, etc. He pays special attention to the white boat trip to Pančevo and the memory of his father and other children and the "walk" to Avala with a relative and a visit to the tomb of the Unknown Hero. However, only when they connect and thus complement the meanings of the caricature and the text of the story, it is concluded that, in fact, the main protagonist of the story is the auto-diegetic narrator (modelled as the author Zuko Džumhur), who all the time in the caricatures and the drawings sadly describes his childhood as an oasis of joy and merriment. But the caricature, shyly, yet very strikingly, says something quite the opposite, especially to the text that accompanies it and completes its meaning: I had very clumsy ears and that's why the girls didn't like me. They made fun of me! I was furious about it, so I beat them. (Džumhur 1991a: 13) While in the previous descriptions the reader gets a picture of a auto-diegetic narrator as a cheerful, obedient and happy boy who enjoys traveling with his family, the cartoon offers his most intimate confession, shame and embarrassment over clumsy ears and a confession that he beat girls who mocked him for sticking ears. This gives the impression that the auto-diegetic narrator "draws" another, perhaps an alternative story or a kind of "story within a story" by drawing. In order not to disturb the harmony of the frame story, or to give the story as a whole an additional dimension.

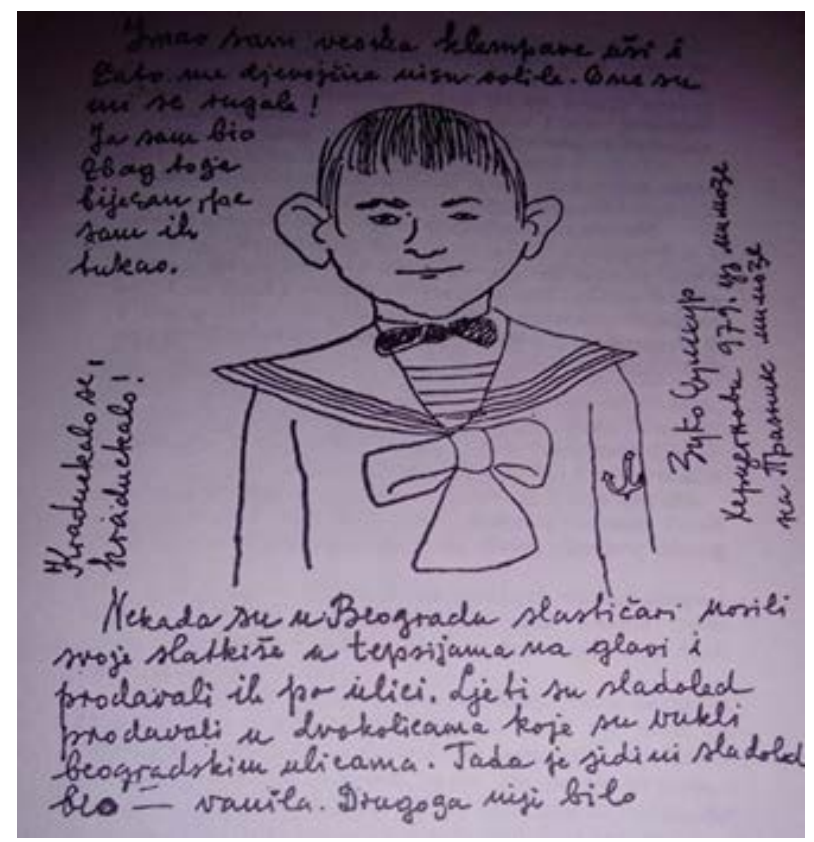

Figure 9. Intimate confession of an autodiegetic narrator with a caricature and text in the story Journey by White Boat (Džumhur 1991a: 13).

In addition to acknowledging the discomfort and rejection due to "clumsy" ears, the auto-diegetic narrator also adds another important piece of information about Belgrade pastry shops, which he did not mention in the frame story, describing the beauty of Belgrade pastry shops with oriental drinks and sweets. All this can be seen in the text of the drawing, the detail that in these patisseries there was only vanilla ice cream and in the left corner another very important intimate confession, which seems as if the joy and presence of the father in the frame story did not allow: There was a little stealing, there was a little stealing! (Džumhur 1991a: 13) In a similar way, the story Oh, Deep Sea (Džumhur 1991a) could join the similarly realized descriptions of a joyfull and above all happy childhood. After describing the sea with which the naive child was delighted, the auto-diegetic narrator will describe in detail the interior where he was accommodated with his family: In one old but clean stone house we took one large room with four beds. There were no mats or rugs on the floor. There were two windows with shutters closed, so that the room was shaded and half-closed. A large crucifix and several framed photographs could be seen on the wall. On one was some bearded man in a sailor uniform.

(Džumhur 1991a: 24) 
Almost to the very end, the story will primarily take place within the enclosed space and experience all that the enclosed space offers: One of the few things left from that old world, besides the church bell towers, some old houses, palm trees and fountains, is my memory of the picture of that sailor on the wall of the room where we lived. (Džumhur 1991a: 26)

As can be concluded from the above quote, the given story is dominated by very impressive intimate descriptions of the interior, and only afterwards the city of Makarska as a place. However, in order to strike a balance since the story is about summer, a rich drawing of the exterior is inserted, i.e. the appearance of the house that complements the story of the summer, which functions as a detailed drawing of the "outer" part of the story. With its intimate text, it also reminds of a kind of a private postcard: Old houses in Makarska. I lived in this high school during the summer with my parents. (Džumhur 1991a:25)

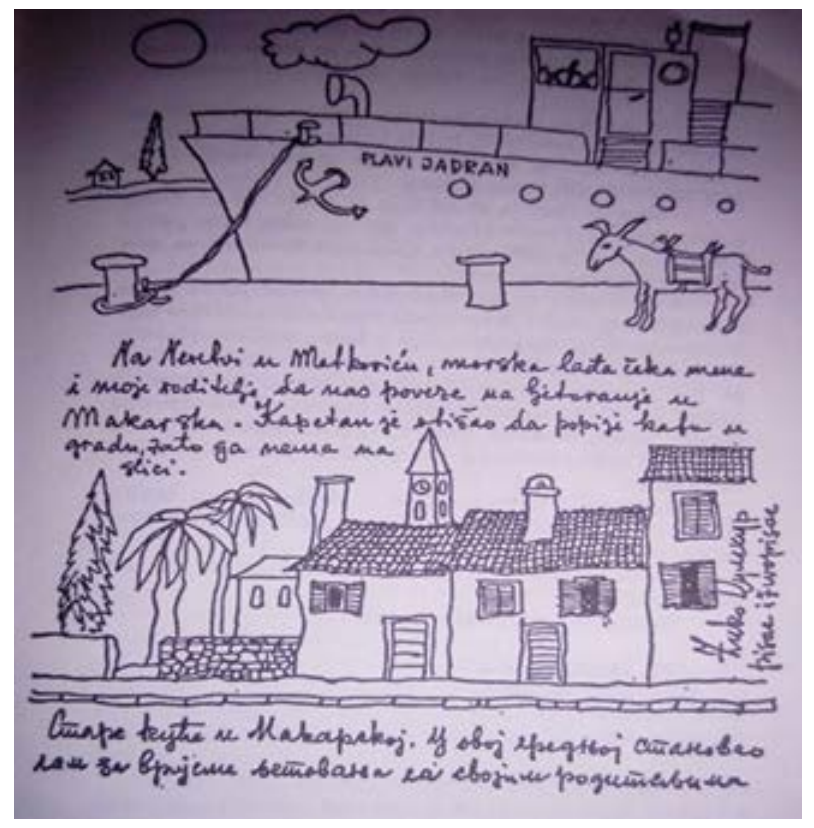

Figure 10. An example of a balance between the "inner" world of the story and the "outer" world shown in the drawing (Džumhur 1991a: 25)

\section{Results}

The story What a life, as well as other stories mentioned in this text, is representative examples of the complexity of the phenomenon of multimediality and intermediality in the work of Zuko Džumhur. It clearly shows how the story itself would not be fully realized or understood without interpreting the drawing that accompanies it, because the drawing depicts its main character Uncle Jelisija, and in the same way everything else that is important for his complete narrative characterization. The same situation occurs in the travelogues (which are more travel stories with all the narrative features of prose, not just descriptions of the place of the travelogue) of this author. The text is complemented by a drawing with its unique meaning. And caricatures and other drawings clearly "speak" about the phenomena of demystification of history, postcolonialism, androgenic worldview, etc. all the important phenomena of today's literature.

These and similar examples are not, of course, rare, rather, they appear throughout Džumhur's travelogue-narrative work. In all these cases, the drawing is by no means just a "visual instrument of the text", but, on the contrary, an integral part of the whole travel-narrative context, and the drawing itself "tells" its story in its own, non-verbal way. It is, therefore, a highly intermediate phenomenon that is imminent to Džumhur's travelogue, and that was also transferred to film, i.e. to television frames, where drawing was replaced by film image, more or less in the same way, i.e. by the same principle. In all of this, in Džumhur's work there are a number of ways of additional thematisation (cf. eg Pirić 2015), and these are primarily: additional thematisation by the history of places that are the subject of travel discourse, additional thematisation by descriptions of various famous historical figures, but seen in a new, different perspective of travelogue narrators, additional thematisation with stories from the childhood of travelogue narrators and additional thematisation with various short jokes and mostly humorous content. All these pre-thematic phenomena are realized in such a way that they make Zuko Džumhur's travelogues ultimately very specific, as it was emphasized, so they should be studied, and the appearance of intermediality, i.e. the relationship between drawings and text can also be considered as an additional thematisation phenomenon.

\section{Discussion}

One could argue why literary criticism in the Balkans did not pay more attention to the study of the work of Zuko Džumhur who was truly ahead of his time. In a strong multimedial and intermedial context, he presented extremely current topics in literature today, from the demystification of history, to postcolonial and gender criticism. Through multimediality and intermediality, he even managed to show the difference between travellers and tourists, and that difference is most striking precisely through his drawings (cf. Pašić Kodrić 2020b). The reasons why literary criticism in the Balkans has not paid much attention to this author to this day might have been sought in the political and social climate of ex-Yugoslavia at the time, but also because travelogues and travel literature have long been ignored because of their "marginal genre character".

Namely, by asking about the general nature of the genre, the relationship between fiction and faction, intertextuality, intermediality, interculturality and the "borderline" of the 
text and its always new and undiscovered meanings, postmodern critical thought opened new doors to travel literature and travelogue, which finally - it seems - gained a well-deserved place of study and evaluation (cf. Pašić Kodrić 2020c).

\section{Conclusions}

Multimedial and intermedial contexts in literature in the Balkans in general deserve more attention in literary criticism, but also more study among scholars and practice among students. Z. Džumhur is the most representative travel author in Bosnia and Herzegovina, but also a very popular author in the South Slavic region, although his work is, unfortunately, very poorly researched. Although the classical literary theory school insisted on the marginal but also "borderline" character of travelogues and travelogues, most often unfairly emphasizing its didactic-pedagogical character, historical significance and educational character in general, this "borderline" that inevitably refers to the multidisciplinary character of travelogues and travelogues literature will be one of the fundamental reasons for their different interpretation and a series of research in that direction. Zuko Džumhur's travelogues show just that on several levels, and here an attempt was made to explain the borderline nature of travelogues through their extremely complex multimedia and intermedia character. In addition to all of the above, in the postmodern era, travelogue as a literary genre is increasingly of interest to the general literary public, largely because of the phenomena of interculturalism, postcolonial critique, gender studies, etc., but also due to the situation of general globalization processes and a number of other extremely complex factors. Precisely because of that, one of the basic tasks of this paper is to present the multimedia and intermedia character of the work of Z. Džumhur.

Z. Džumhur's travelogues are by no means mere descriptions of different places and cultures, i.e. travelogues in the classical, traditional sense, but true travelogues and postcards with their additional thematisation, with all the features of prose and narrative discourse in general.

\section{Acknowledgements}

This article was partly presented at the "6th International Conference on Lifelong Education and Leadership for AALL” held at Sakarya University on July 6-8, 2020.

\section{REFERENCES}

[1] Džumhur, Zuko. (1991a). „Neuhvatljivi Andrićev lik“.
Putovanje bijelom lađom. Oslobođenje. Sarajevo

[2] Džumhur, Zuko. (1991b). „Mostar“. Adakale. Oslobođenje. Sarajevo

[3] Džumhur, Zuko. (1991c). „Nekrolog jednoj čaršiji“. Nekrolog jednoj čaršijii. Oslobođenje, Sarajevo

[4] Džumhur, Zuko. (1991d). „U odajama El Eskorijala“. Hodoljublja. Oslobođenje. Sarajevo

[5] Halilović, Senahid et. al. (2010). Rječnik bosanskoga jezika. Filozofski fakultet. Sarajevo

[6] Intertekstualnost \& intermedijalnost (1988), ed. Zvonko Maković et. al. Zavod za znanost o književnosti Filozofskog fakulteta Sveučilišta u Zagrebu. Zagreb

[7] Kapor, Momo, Džumhur, Zuko. (1993). Zelena čoja Montenegra. Prosveta. Beograd

[8] Lipski, Jakub. (2018). Travel and Identity: Studies in Literature. Culture and Language. Cham: Springer International Publishing AG part of Springer Nature

[9] Pašić, Mirzana. (2012). Putovanje kao priča: Putopisi Zuke Džumhura. Magistarski rad. Filozofski fakultet Univerziteta u Sarajevu. Sarajevo

[10] Pašić Kodrić, Mirzana. (2015). „Putopisi Zuke Džumhura i njihov pripovjedač (Od bijega u djetinjstvo do povratka u historiju)“, Naučni skup „Slovo o Aleksi Šantiću, Antunu Branku Šimiću i Zuki Džumhuru ": Zbornik radova, Fakultet humanističkih nauka Univerziteta „Džemal Bijedićc" u Mostaru. Institut za jezik Univerziteta u Sarajevu. Mostar. Sarajevo

[11] Pašić Kodrić, Mirzana. (2017). Putopisno-pripovjedačko djelo Zuke Džumhura (Književnoteorijski,književnohistorijs ki i metodički pristup). Doktorska disertacija, Fakultet humanističkih nauka Univerziteta „Džemal Bijedić“ u Mostaru. Mostar

[12] Pašić Kodrić, M. (2020). IDEOLOGIES OF TERRITORIAL OWNERSHIP, GLOBAL POSSESSIVEN ESS AND GENDER IN ZUKO DȚUMHUR'S TRAVELOGUES. Knowledge International Journal, 42(6), 1083 - 1087. Retrieved from http://www.ikm.mk/ojs/index. php/KIJ/article/view/4656

[13] Pašić Kodrić, M. (2020). TOURISTS AND TRAVELERS IN THE TRAVELOGUES OF ZUKO DȚUMHUR. Knowledge International Journal, 42(6), 1101 - 1105. Retrieved from http://www.ikm.mk/ojs/index.php/KIJ/articl e/view/4658

[14] Pašić Kodrić, M. (2020). TRAVELOGUE AND CONTEMPORARY INTEREST IN "BOUNDARY LITERARY GENRES”. Knowledge International Journal, 38(6), 1391 - 1394. Retrieved from http://ikm.mk/ojs/index. php/KIJ/article/view/3837

[15] Pirić, Alija. (2015). Mogućnosti čitanja teksta: Studije o Ivi Andriću i Zuki Džumhuru. IC štamparija. Mostar

[16] Radioenciklopedija bh. stvaralaštva - Hodoljublja. (2015). Radio Federacije Bosne i Hercegovine. Sarajevo

[17] Rječnik stranih riječi bosanskog jezika (2011). Institut za jezik. Sarajevo

[18] Tijanović, Hasan. (2008). Multimedijalnost putopisa Zuke 
